DOI: https:// doi.org/10.25217/jcd.v1i2.1861 | Accepted 29'Sept 2021 | Published 30'Sept 2021

\title{
Mathematical Games Using Real-World Approaches Increasing Kindergarten Students' Learning Creativity
}

\author{
Choirudin \\ Institut Agama Islam Ma'arif NU (IAIMNU) Metro Lampung \\ choirudiniaimnumetro@gmail.com \\ Masrurotul Mahmudah \\ Institut Agama Islam Ma'arif NU (IAIMNU) Metro Lampung \\ mahmudahmasrurotul1@gmail.com \\ M. Saidun Anwar \\ Institut Agama Islam Ma'arif NU (IAIMNU) Metro Lampung \\ saidun.anwar@gmail.com \\ Yuli Ani Setyo Dewi \\ STITNU Al Hikmah Mojokerto \\ yulianisetyo85@gmail.com \\ Dhita Paranita Ningtyas \\ Universitas Trilogi Jakarta \\ dhita@trilogi.ac.id
}

\begin{abstract}
Many parents think that games are a waste of time and not useful, so they forbid their children to play, and as a result, the children's soul will be depressed and the words naughty child, cougar, passive, and so on. This assumption is caused by the fact that parents do not fully understand their personality, characteristics, tendencies, and child nature. By looking at conditions like this, Kindergarten is expected to strive to implement the function of play by children's growth and development by providing the freedom to each child accompanied by the cultivation of constructive values Research objectives. To determine the game method's implementation using a real-world approach to increase children's learning creativity in TK Ma'arif 22 Trimurjo. The technique used for this research is qualitative. Subjects were students included and engaged in math games with the real-world: in-depth interview data collection techniques, observation, and documentation. In the implementation of playing activities, students' attitudes are given the freedom to develop their potential and creative power according to their talents and interests. In this case, it can be proven by the games at TK Ma'arif 22 Trimurjo. Mathematical games using a real-world approach in increasing the learning creativity of kindergarten students.
\end{abstract}

Keywords: Creativity, Kindergarten, Mathematics Games Approach, Real-world

(C) 2021 Choirudin, Masrurotul Mahmudah, M. Saidun Anwar, Yuli Ani Setyo Dewi, Dhita Paranita Ningtyas

This work is licensed under a Creative Commons Attribution-ShareAlike 


\section{INTRODUCTION}

Education is so essential in human life. In a nation, education is the main factor determining the country's progress(Widodo 2016). Education has a significant influence on development. Having an education can produce competitive human resources globally(Richman 2015:122) - one way to improve the quality of teaching and learn in Kindergarten (TK). Students are taught three necessary abilities at this level of education: cognitive, affective, and psychomotor skills(Hoque 2017). If students are less able to master these three abilities, they will experience difficulties taking education at a higher level. Learning in Kindergarten has a vital role because it is the foundation for further instruction.

Kindergarten is one of the educational institutions that have an essential role in children's growth and development in the future. Because in addition to being the first step in escaping from the family environment, it is also an initial effort to bring children to a stable mental preparation to step into the educational process. Kindergarten is a pre-school educational institution that aims to develop children's abilities(Loukatari et al. 2019). As has been expressed by experts in child education, Deutsch and Hechinger stated that it is not valid if we just stay silent and wait for development to come. Both the development of the intellect and the development of children's behavior needs to be guided and stimulated. It means that a sensitive period or needs to be produced. All children can learn as quickly as possible(Brezinka 2012).

Playing is a common symptom in the animal, children, youth, and adults. Games are chosen by themselves without any element of coercion, without being pressured by a sense of responsibility. As Kartini Kartono (in Adiebah(Adiebah 2020)), playing is an essential means of socializing children, introducing children to become members of society to know and respect human society. In the atmosphere of the game, a sense of harmony grows, which is very important for forming the social soul as human culture. Improving the quality of human resources is an absolute prerequisite for achieving educational goals. As a determining factor for education success, human resources' quality is enhanced through educational programs carried out systematically and directed based on interests that refer to advances in science and technology (IPTEK) and based on faith and devotion (IMTAQ)(Mulyasa 2015).

However, many parents think that games are a waste of time and are not useful, so that they often forbid their children to play. As a result, the children's soul will be depressed, naughty, disruptive, passive, and so on, will arise. This assumption is caused by the fact that parents do not fully understand the children's personality, both their characteristics, tendencies, and children's nature. Kindergarten is expected to strive to implement the function of play. Children's growth and development by providing the freedom to each child accompanied by the cultivation of religious values for children's provision in the future, they become people who believe and devote to Allah SWT.

To find out children's mathematical cognitive abilities, researchers observed 20 students at TK Ma'arif 22 Trimurjo. In practice, students memorize numbers and perform addition 
operations just by writing in books, so a unique approach is needed to increase children's creativity. The survey results are corroborated by the expression Schindler and Lilienthal "Mathematics problems are challenging. I did not know how to do it. That's why I did not finish it. I don't like Maths"(Schindler and Lilienthal 2020). The students struggled with mathematical problem solving, which manifested themselves in various ways to deal with difficulties in gaining knowledge and skills.

In presenting engaging learning, should teachers do educational interaction with the understanding by doing principle? This educational interaction process applies the principle of education as well as playing. The learning process will be successful when students feel active, happy, creative, and tend not to be binding(Djamarah and Zain 2016). Learning by games is considered an innovative approach to education and has influenced student learning behavior with more active knowledge and motivation to engage in learning(Hsieh, Lin, and Hou 2016:178-79).

According to Shoba Dewey Chugan,(Shoba Dewey Chugan Chugani 2010:12) a child can get useful experiences in playing activities. A teacher has so many opportunities to teach various things through games, including forming mathematical cognitive abilities. Learn and play are two activities that are very urgent and complementary. Playing makes children happy to learn, and by learning through play, children can master more challenging lessons(Triharso 2013:6).

When children play, they are also learning. Adopting learning time with games is one way every children's play can be a place for them to learn(Murniati 2012:23). Steps that educators can take are determining the type of fun to be used-the emphasis on learning while playing sites a priority on learning over games. The game is only a means, not an end.

The existence of games in a learning process makes the learning process ineffective for children. They think that later children will want to play more than learning. Games have a significant influence on children's mental development. Moreover, if the game is appropriately designed, playing is also a useful learning tool by combining recreational, creative, and educational aspects to create the right learning environment(Licorish et al. 2018).

Abramovich said: When teachers construct real and critical events, their creativity model for students, and use space creatively, creative learning is likely to occur(Abramovich, Grinshpan, and Milligan 2019). When teachers provide fundamental and essential education for students, creative learning is expected to occur. Games are activities that aim to acquire skills excitingly(Mujib and Rahmawati 2013:19). In using the game method, the teacher should use the right approach to spur creativity in learning. One that is offered is a game with a real-world system. Using a real-world approach is essential in schools to help children build creativity in education. This concept can encourage students to think and talk about the world around us. Teachers can help connect mathematics to everyday life.

For many students, mathematics seems too abstract. When it can be related to things they see and do in everyday life, the concepts become real and meaningful. 
The activities here all involve doing something. It is not enough to think about things. When you do something in the real world, there is usually a reaction someone or something does back(Nonesuch 2008:1). According to Adam Ishaq et al., more significant in the simulation game of the conventional teaching methods(Ishaq et al. 2019). Elizabeth emphasized the game method appears to be more effective in increasing students' interest in learning(Hanson-Smith 2016:231). Through the game, the approach will lead students from creativity to achievement in education.

For creativity, Barron (in Utami Munandar(Munandar 2012:21)) defines it as producing/creating something new. Imagination forms the four capabilities that children have, psychological, intelligence, cognitive, and personality. These four aspects of the mind will help understand what creates a creative individual. Mathematical creativity plays an essential role in learning mathematics. The invention in mathematics can be characterized in several ways, such as divergent and flexible thinking or "unusual" and in-depth solutions to a given problem(Katz and Stupel 2015:68).

We are developing a game method using a real-world approach focused on the children's/student's life to develop cognitive, affective, and psychomotor values while creating communicative situations, enabling them to convey authentic messages about exciting information.

\section{Mathematical Games with a Real-World Approach}

The real-world approach began to grow due to a desire to review the re-education seemed less meaningful to mathematical learners(Mujib and Rahmawati 2013). In its view, mathematics must be related to reality, close to children's experiences, and relevant to society to be part of human values. Apart from viewing mathematics as a transferred subject, Freudenthal emphasized mathematical ideas as human activities. Mathematics lessons should allow students to be "guided" and "rediscovered" mathematics by doing it. In mathematics education, the main objective is mathematics as an activity and not a closed system(Tedja 2012:45).

Learning the real mathematical world is mathematical learning approaches are made by placing students' realities and experiences as a starting point of learning. Furthermore, students are allowed to apply mathematical concepts to solve daily problems in other fields. This learning is very different from mathematics learning, which has tended to be oriented towards providing information and using mathematics that is ready to be used to solve problems.

In their research, childhood education experts stated that the most effective way of learning for children in their learning activities(Ismail 2010:25). Operations for kindergarten education will be more meaningful if carried out through educational methods that are fun, educational, interests, talents, and personal needs. Therefore, they need games as an education media in learning. Play tools do not have to be expensive. The educational element must take precedence. It will be more apparent if you deliver learning material with a learning-by-playing approach(Ismail 2010). 
According to Dewey,(Shoba Dewey Chugan Chugani 2010) a child can get useful experiences in playing activities. Through games, educators have many opportunities to teach various things, including learning mathematics. Learning and playing are two essential and complementary things. Playing makes children learn happily and can master more challenging lessons(Triharso 2013). When children play, they are learning. Observing learning time with games is one way each children's play can become a place for them to learn(Murniati 2012). The steps that educators can take determine the types of games they want to use. This game is only limited to facilities, not as an objective.

Some argue that play in the learning process makes learning ineffective for children. They think that later children will want more games than education(Triharso 2013). Games have a significant effect on the mental development of children. Especially if the game is well designed, playing is also a useful learning tool by combining recreational, creative, and educational aspects and creating the right learning environment(Tok 2015).

In using the game method, the teacher must use the right approach to stimulate motivation and creativity in learning, one of which is being offered is a game with a realworld system to play, toys, and fun. The play method using the real-world approach is essential in schools to help children build motivation and creativity in learning, especially in mathematics. This concept can encourage students to think and talk about the world around us. Teachers can help connect mathematics with everyday life with school mathematics.

To many students, mathematics seems too abstract. When it can be linked to the things they see and do in their daily life, the concept becomes real and meaningful(Giganti 2010). All activities here involve doing something. It's not enough just to think about things. When you do something real, there is usually a reaction from someone or something doing something back(Nonesuch 2008).

\section{Learning Creativity}

Creativity is the ability to create new combinations based on existing data, information, or elements. Usually, people define creativity as creativity, as the ability to create new things. The more experienced and knowledge a person has, the more likely he is to use and use all this experience and expertise to engage himself creatively. To be able to make something meaningful, preparation is needed(Munandar 2012).

Many activities can be designed by the educator, all of which is to enhance children's creativity. Developing children's creativity always requires children to think of various possible answers and solve problems. It is called divergence, assuming in multiple directions, in contrast to convergent thinking, where the child is directed to give one of the most appropriate answers to a problem(Munandar 2012). Thus, it can be concluded that the idea of creativity is the ability of a person to produce a composition, production, or any idea that is fundamentally new and previously unknown to the author. It can be an imaginative activity or a synthesis of thoughts whose results are not just summaries. It may include forming new patterns and combining information gleaned from previous experiences, transplanting old relationships into new situations, and forming new 
correlations. It must have a defined purpose, only open fantasy, even if it is a perfect and complete result. It may be in the form of an artistic product, literature, scientific product, or procedural or methodological(B. Hurlock 2010:4).

Creativity brings joy and satisfaction to children. For example, nothing can give children greater satisfaction than creating something yourself, whether it be a house made of an upside-down chair covered in a blanket or a picture of a dog. And nothing detracts further from self-esteem than criticism or ridicule of creation or the question of what form it takes.

Being creative is also essential for young children because it adds spice to their play as the center of their life. One of the critical values of creativity that is often overlooked is its contribution to leadership. Besides the personal satisfaction that children get from imagination, if that creativity increases the sense of pride in playing the role of leader, this will guarantee a good social and personal adjustment scene.

The value of creativity is evident in the case of less creative children. Spock says very literal-minded people have limited utility to the world and a limited ability to derive joy(B. Hurlock 2010). Why is creativity essential to be nurtured and developed in children. First, because creating humans can manifest themselves, self-realization is one of the basic human life needs. Second, creativity or creative thinking as the ability to see various possible solutions to a problem is a form of thinking that has not been given much attention to informal education. Third, creative self-activity is not only beneficial but also satisfies the individual. It will be evident if we observe children engrossed in playing with wooden blocks or other constructive play materials. Fourth, creativity is what enables humans to improve their quality of life(Munandar 2012).

Several things jeopardize an excellent fit in various areas of creativity, among others(Keong 2006):

a) Failure to stimulate creativity

Lack of stimulation can be caused by parents' and others' ignorance in the baby's environment about the importance of creativity. It may be caused by the assumption that creativity is innate so that nature will regulate its development, and therefore, stimulation is not needed.

b) Inability to detect creativity at the right time

Under such conditions, it is not surprising that the stimuli for the development of creativity are ignored. When there is evidence that children have creative potential, it may be too late to provide incentives that can fully develop that potential.

Unless tests or other methods can be designed to detect creativity at an early age, the only way to overcome this danger is to assume that every child has the potential to be creative, even to varying degrees, and to provide them with the necessary stimulation until an early age.

c) Disliked social attitudes to creativity

This inhibiting factor is manifested in 2 general forms, namely: first, a non-positive attitude towards creative feet, and second, a lack of social appreciation for creativity. Although these children have many great ideas, they are quickly said to have strange, irrational, or naughty thoughts. It is difficult to determine their personal development and 
creative talents in the future. These characteristics may make their behavior more difficult to predict, and it may make their presence in a group troublesome.

d) Unfavorable school conditions

Among the many schools that discuss developments in schools with a large number of disciplinary needs, the stress of the memorization process, the prohibition of anywhere that does not conform to the original, scheduled classroom events, classroom and strict discipline, and teachers' beliefs about children who are more challenging to complete their work and jobs for children.

\section{METHODOLOGY}

The approach used for this research is qualitative. Qualitative research deals with the ideas, perceptions, opinions, or beliefs of the people being studied, all of which cannot be measured by numbers. Qualitative research aims to obtain a complete picture of something according to the human perspective being studied. In qualitative research, the researcher is the primary research tool. Moleong explains qualitative research as research that is intended to understand the phenomena experienced by research subjects such as behavior, perception, motivation, action, etc., holistically (intact), and using descriptions in the form of words and language, at specific contexts that are natural and by making use of various natural methods.(2014)

Besides, Sugiyono also argues that qualitative research as a research method based on the philosophy of positivism is used to examine the conditions of natural objects, where the researcher is a crucial instrument, data collection techniques by triangulation, inductive or qualitative data analysis, the results of qualitative research emphasize the meaning. Rather than generalizations(2017).

According to Nana Syaodih Sukmadinata, qualitative descriptive research aims to describe and describe existing phenomena, both natural and human, that pay more attention to characteristics, quality, and linkages between activities(Syaodih Sukmadinata 2011:73). Besides, descriptive research does not provide treatment, manipulation, or alteration of the variables under study but describes a condition as it is. The only treatment given is the research itself, carried out through observation, interviews, and documentation.

The type of research conducted by researchers is case study research. A case study is a qualitative research in which researchers conduct in-depth exploration of programs, events, processes, activities to one or more people. A case is bound by time and action, and the researcher collects detailed data using various data collection procedures and in continuous time(2017).

\section{RESULTS AND DISCUSSION}

The purpose of playing mathematics is to optimize the child's overall development and interactive communication. Therefore, playing mathematics at Ma'arif 22 Trimurjo Kindergarten can run well. A learning strategy is needed for children-oriented towards objectives, materials, methods, media or game tools, and evaluation by the child's development obtained based on the results. Observation, interview, and documentation. 
Description of playing math activities in children's early activities doing arithmetic activities carried out by children outside the room before entering the class to remember the sequence of numbers, counting numbers 1-10, and mentioning the various vehicles or animals land. Mathematics playing activities in class are carried out by clapping two patterns, saying the number of friends who are not present in class, telling stories about personal experiences, mentioning the name of the day, date, month, and year, counting using algebraic fingers and motor activity activities.
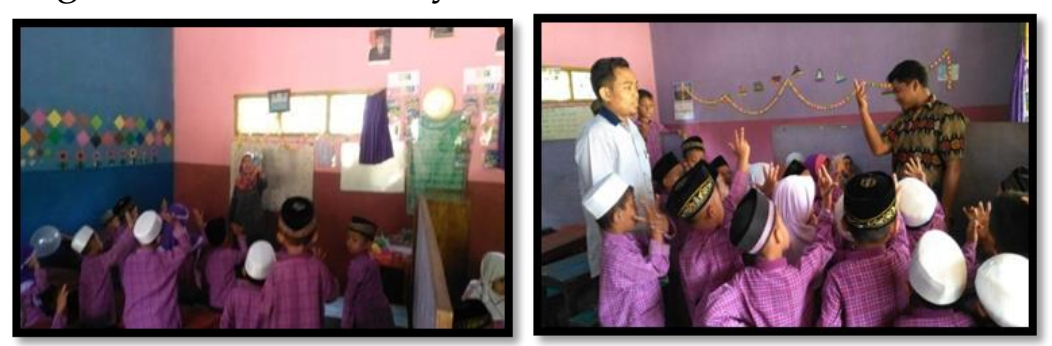

Figure 1 \& 2

Playing Maths Finger Algebra and Motor Activities

The main activities outside the classroom are playing line charts, mentioning the vehicle's name on the highway, playing counting steps, playing where my fish is, and observing the boat. Mathematics playing activities in the classroom include tracing geometric shapes, playing toy cars, working on student worksheets, sorting objects from largest to smallest, folding fish shapes, building boats, and forming trains from geometric pieces.

In mathematics playing activities, the teacher uses playing, singing, telling stories, field trips, chatting, question and answer, and dramatization. All of the teacher's methods are play activities, where when children do play activities, the children are happy. The essence of play includes feeling happy, democratic, active, not forced, and free to become the soul of every activity.

Math play activities in terms of children's participation include individual and group activities. Individual play is a play performed by a child, such as counting activities according to sequence, leaning on the child's own fingers the numbers 1-10, mentioning land vehicles, and telling stories about their personal experiences. From this activity, the teacher has a goal to determine the child's ability about the child's knowledge while studying at school and the understanding that the child gets to share with the teacher and his friends.

Group play is performed by several children, such as: clapping two patterns, mentioning the number of presents and not present in class, counting using algebraic fingers, and motor activities. This activity is carried out classically or in groups in the classroom because the teacher aims to find out the children's enthusiasm in the class with the participation of children in groups, observing children's development through the interaction of children with friends, children with their teachers in harmony. In the individual activity, the teacher aims to know each child's abilities about child's abilities as a report on the development of unique children's learning outcomes. Learning through 
playing, children can manipulate objects that children see, and children can explore, imagine, and create on their own with game tools, teaching resources, and media used in math play activities. Mathematics playing activities are viewed from the tools and materials used by children at TK Ma'arif 22 Trimurjo.

The results of interviews with class teachers, children were taught mathematical concepts through playing activities using tools and play materials around the child and using concrete objects (real-world), for example, using children's limbs through applause, number of families, children's house numbers, number of friends, and so on. Therefore, the teacher considers that the child's environment is the largest laboratory as a learning source. Through the environment, children can learn many things, imagine, explore through play, and feel happy.

In playing mathematics activities using concrete objects (real-world) and carried out directly by the child, where the five senses of the child are directly involved so that the child gets knowledge from the children's interaction with the environment instantly, play activities are also adjusted to the children's developmental stage according to with their age. A conducive and varied classroom atmosphere is needed to not be bored and bored in learning in the classroom. The principle of playing mathematics has several functions, including developing all aspects of child development according to their developmental stages, being able to introduce children to the world around them, developing children's socialization, introducing simple rules in play and instilling children's discipline, and providing opportunities for children to enjoy playing it.

The mathematics playing activities in TK Ma'arif 22 Trimurjo, the mathematics taught in mathematics playing activities, are as follows: the content of playing mathematics must be rich, varied, concept-oriented, and goal-focused. Understand mathematics, and children are taught about mathematical concepts through play activities. Playing math activities must provide opportunities for children to solve simple problems. The physical environment must cover concrete media (real-world) that can be manipulated (blocks, ten basic blocks, patterned blocks, various kinds of partnerships, tangram and counting stuffed animals, plastic toy balls, etc.), symbol media (dice, dominoes, number lines, graphics, computer programs, and other visual media) and abstract media (plastic numbers, list of foodstuffs, 100 tables, building plans, calculator, computers and so forth). The teachers consider the ability of a specific child in the class.

The design of playing mathematics requires planning, interacting with children, creating a conducive environment (moving class), schools establishing cooperative relationships with parents, and assessing all aspects of child development to be reported to parents. Playing as an implementation of learning in early childhood provides various benefits to developing potential children's development.

As stated by Freeman and Munandar, the benefits obtained from the play are: as a channel for the excess energy of children, as a means to prepare for their future life, as a continuation of the image of humanity, to build lost strength, to get compensation for things 
that are not acquired, play allows children to release feelings and emotions and provides a stimulus to the personal formation(Munandar 2012).

Based on this concept, the study results show that the teachers at TK Ma'arif 22 Trimurjo have used the idea of playing while learning with the approach of real objects around which students are familiar (real-world).

Learning is structured in a fun, fun, and democratic way to attract children to be directly involved in learning activities. Children sit quietly listening to the teacher's lecture, but children actively interact with various objects and people in their environment, both physically and mentally. For this reason, in the learning process in early childhood, it is necessary to organize a conducive and varied learning environment, mathematics playing activities in terms of the place where mathematics playing activities can be carried out indoors and outdoors.
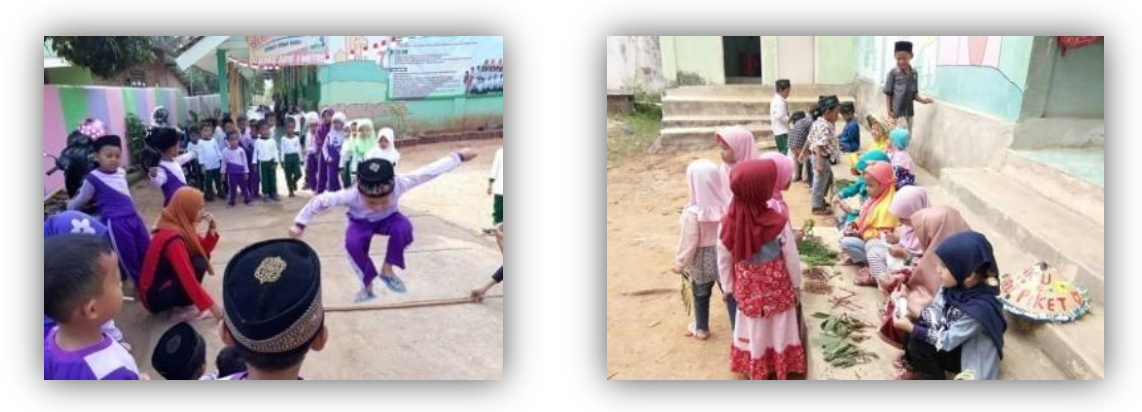

Figure $3 \& 4$

Outdoors Playing Activities

The results of observations in TK Ma'arif 22 Trimurjo that the class atmosphere is designed in a conducive way, changes in patterns in the classroom that are structured with decorations that are suitable for the child, and the placement of play equipment are also neatly placed so that the children are free to do learning activities in the classroom such as clapping hands, tracing geometry, arranging geometric pieces into a train, drawing, folding and so on. The study's findings show that playing math activities can be done outside the classroom because of an outside classroom environment. Children are freer to play freely, express, explore, and imagine interacting with the territory, friends, and people around the child.

Playing mathematics activities in terms of children's participation in TK Ma'arif 22 Trimurjo, children can play individually or in groups, according to early childhood learning, among others: children learn through play, children learn with peers, learning according to children's needs, and teaching in an integrated manner. Children Learn through Interaction, namely: Children learn through play tools and interactions with people around the child.

The early childhood learning environment needs to be enriched with learning experiences. Play equipment should be selected based on several criteria, namely: according to the child's age and level of development, quality design and by the characteristics of the 
child, durable, flexible, and multifunctional in terms of use, safe for children (non-toxic paint, no sharp edges, and corners), and exciting colors and shapes.

Whether or not children are active in learning begins with the emergence of a sense of interest and interest in the children themselves in following lessons. The achievement of learning objectives is not seen from fulfilling the target material that must be given. Still, how interested the child is to know and understand the teaching material, for that we need a useful, engaging, and fun learning approach for students, one of which is by playing using a (real-world) method.

Children learn through play because playing is an activity that contains a sense of pleasure and is more concerned with the process than the result. Types of games must be adapted to the level of development, age, and abilities of the child, so that all kinds of games can be developed gradually, starting from playing while learning (the element of play is greater) to the level of learning while playing (the aspect of education is greater).

It is under the characteristics of early childhood who like to play. This characteristic requires kindergarten teachers to carry out learning activities that contain games, especially for early childhood. Kindergarten teachers should design a learning model that allows for an element of play in it.

Play is an essential instrument for children's social, emotional, and cognitive development. Besides that, it is also a reflection on children's development. Playing can also foster children's creativity. During play, a child learns to cope with emotions, interact with others, cope with conflicts, and get a feeling of competence. Through play, children can develop children's imaginations and creativity. In other words, playing is an essential requirement for children.

The world of children is a world that is identical to play, especially at an early age. Playing can support the growth of students' cognitive, affective, and psychomotor aspects. Through playing while learning, abstract mathematical concepts can be more easily understood by students. Therefore, teachers' initiative and support in designing and implementing learning that accommodates children's play needs are essential in learning practices appropriate to the child's developmental stages.

Playing mathematics activities have several functions, including developing all aspects of child development according to their developmental stages, being able to introduce children to the world around them, developing children's socialization, introducing simple rules in play and instilling children's discipline, and providing opportunities for children to enjoy playing.

\section{CONCLUSION}

Based on the results of research on the mathematical game method using the real-world approach in increasing children's learning creativity in TK Ma'arif 22 Trimurjo, it can be concluded as follows: In the implementation of play activities, students' attitudes are given the freedom to develop their potential and creative power according to their talents and abilities. It can be proven that the games at Ma'arif 22 Trimurjo Kindergarten are very 
suitable for children's psychological conditions. They will be able to get happiness and channel and develop their excess energy, as well as psychological harmony, making them aware of the essence of humanity. In the child, his honour, pride, and strength. Meanwhile, mathematics games using a real-world approach increase effectiveness in increasing kindergarten students' learning creativity.

\section{ACKNOWLEDGEMENT}

We would like to thank the Journal of Childhood Development which has received and published the articles we have submitted, thanks also to all stakeholders involved in the completion of our research.

\section{REFERENCES}

Abramovich, Sergei, Arcadii Z. Grinshpan, and David L. Milligan. "Teaching Mathematics through Concept Motivation and Action Learning." Education Research International 2019 (April 14, 2019): e3745406. https://doi.org/10.1155/2019/3745406.

Adiebah, Rina. Meningkatkan Kualitas Anak Optimalisasi Kecerdasan IQ,EQ dan SQ. Banten: Rumah Belajar Matematika Indonesia, 2020.

B. Hurlock, Elizabeth. Perkembangan Anak. Jakarta: Erlangga, 2010.

Brezinka, Wolfgang. Philosophy of Educational Knowledge: An Introduction to the Foundations of Science of Education, Philosophy of Education and Practical Pedagogics. Basel: Springer Science \& Business Media, 2012.

Djamarah, Syaiful Bahri, and Aswan Zain. Strategi Belajar Mengajar. Jakarta: Rineka Cipta, 2016.

Giganti, Paul. Helping Your Children Learn and Enjoy Mathematics Math At Home. California Math Project: North Coast. and California Mathematics Council, 2010.

Hanson-Smith, Elizabeth. "Games, Gaming, and Gamification: Some Aspects of Motivation." TESOL Journal 7, no. 1 (March 2016): 227-32. https://doi.org/10.1002/tesj.233.

Hoque, M. Enamul. "Three Domains of Learning: Cognitive, Affective and Psychomotor." The Journal of EFL Education and Research (JEFLER) 2, no. 2 (January 1, 2017): 45-51.

Hsieh, Ya-Hui, Yi-Chun Lin, and Huei-Tse Hou. "Exploring the Role of Flow Experience, Learning Performance and Potential Behavior Clusters in Elementary Students' Game-Based Learning." Interactive Learning 
Environments 24, no. 1 (January 2, 2016): 178-93. https:/ / doi.org/10.1080/10494820.2013.834827.

Ishaq, Adam, Tolulope Latunde, David Ogwumu, Adeniyi Mustapha, and Joel Ajinuhi. "Impacts of Simulation-Games on Teaching and Learning Mathematics." Journal of Sciecnce Technology and Education 7, no. 4 (October 1, 2019).

Ismail, Andang. Education Games, Menjadi Cerdas Dan Ceria Dengan Permainan Educatif. Yogyakarta: Pilar Media, 2010.

Katz, Sara, and Moshe Stupel. "Promoting Creativity and Self-Efficacy of Elementary Students through a Collaborative Research Task in Mathematics: A Case Study." Journal of Curriculum and Teaching 4, no. 1 (March 8, 2015). https:/ / doi.org/10.5430/jct.v4n1p68.

Keong, Yew Kam. 30 Kiat Mencetak Anak Kreatif Mandiri. Bandung: Penerbit Nuansa, 2006.

Lexy J. Moleong. Metode Penelitian Kualitatif. Bandung: PT Remaja Rosdakarya, 2014.

Licorish, Sherlock A., Helen E. Owen, Ben Daniel, and Jade Li George. "Students' Perception of Kahoot! 's Influence on Teaching and Learning." Research and Practice in Technology Enhanced Learning 13, no. 1 (July 21, 2018): 9. https:/ / doi.org/10.1186/s41039-018-0078-8.

Loukatari, Paschalio, Ourania Matsouka, Katerina Papadimitriou, Semina Nani, and Vasilis Grammatikopoulos. "The Effect of a Structured Playfulness Program on Social Skills in Kindergarten Children." International Journal of Instruction 12, no. 3 (July 3, 2019): 237-52. https:/ / doi.org/10.29333/iji.2019.12315a.

Mujib, Fathul, and Nailur Rahmawati. Metode Permainan-Permainan Edukatif Dalam Belajar Bahasa Arab. Yogyakarta: Diva Press, 2013.

Mulyasa, E. Kurikulum Berbasis Kompetensi. Bandung: Remaja Rosda Karya, 2015.

Munandar, Utami. Pengembangan Kreativitas Anak Berbakat. Jakarta: Rineka Cipta, 2012.

Murniati, Endyah. Pendidikan Dan Bimbingan Anak Kreatif. Yogyakarta: Pustaka Insan Madani, 2012.

Nonesuch, Kate. Family Math Fun. Duncan: Vancouver Island University Cowichan Campus, 2008.

Richman, Nicole. "Human Resource Management and Human Resource Development: Evolution and Contributions." Creighton Journal of 
Interdisciplinary Leadership 1, no. 2 (November 16, 2015): 120. https://doi.org/10.17062/cjil.v1i2.19.

Schindler, Maike, and Achim J. Lilienthal. "Students' Creative Process in Mathematics: Insights from Eye-Tracking-Stimulated Recall Interview on Students' Work on Multiple Solution Tasks." International Journal of Science and Mathematics Education 18, no. 8 (December 1, 2020): 1565-86. https://doi.org/10.1007/s10763-019-10033-0.

Shoba Dewey Chugan Chugani. Anak Yang Bermain, Anak Yang Cerdas. Jakarta: Gramedia Pustaka Utama, 2010.

Sugiyono. Metode Penelitian Kuantitatif, Kualitatif, Dan RED. Bandung: CV. Alfabeta, 2017.

Syaodih Sukmadinata, Nana. Metode Penelitian Pendidikan. Bandung: PT Remaja Rosdakarya, 2011.

Tedja, Saputra. Bermain, Mainan Dan Permainan. Jakarta: Grasindo, 2012.

Tok, Şükran. "The Effects of Teaching Mathematics Creatively on Academic Achievement, Attitudes towards Mathematics, and Mathematics Anxiety." International Journal of Innovation in Science and Mathematics Education 23, no. 4 (December 9 , 2015). https:/ / openjournals.library.sydney.edu.au/index.php/CAL/article/view/ 7887.

Triharso, Agung. Permainan Kreatif Dan Edukatif Untuk Anak Usia Dini. Yogyakarta: Andi Yogyakarta, 2013.

Widodo, Heri. "Potret Pendidikan Di Indonesia Dan Kesiapannya Dalam Menghadapi Masyarakat Ekonomi Asia (MEA)." Cendekia: Journal of Education and Society 13, no. 2 (April 4, 2016): 293. https://doi.org/10.21154/cendekia.v13i2.250. 